\title{
Metaforizáció és nyelvszemlélet a nyelvújítás diszkurzusában ${ }^{1}$
}

\section{Bevezetés}

A magyar nyelvújítás címü, negyedszázaddal ezelött írt tanulmányát Tolcsvai Nagy Gábor (1995: 370) ezzel a nem alaptalan - de aztán mások mellett éppen saját, új szempontok érvényesítésével új meglátásokat kidolgozó tanulmányaival többször is megcáfolt - kételynek a felvetésével indította: „Talán elcsodálkozhat az olvasó [...], hogy olyan témát jelöl a fenti cím, melyet már ezerszer tárgyaltak a szakma klasszikusai, és bizonnyal lehetetlen újat vagy érdekeset mondani róla." A jelen dolgozat vonatkozásában bennem is felmerülő „,mi újat, érdekeset lehet még mondani a nyelvújításról?" kérdéssel összefüggésben, a téma legáltalánosabb előzetes megközelítésekor szükséges azonban nyomatékosan arra is utalni, hogy a nyelvújításról - mint ezt részben éppen a régebbi és a legújabb vonatkozó szakirodalom rendkívüli bősége is jelzi - számos lezáratlannak túnő értelmezés, értékelés létezik ma is egymás mellett, nemegyszer egymás ellenében. Ezzel függ össze az is, hogy elsődlegesen irodalomtudományi szempontból, de a nyelvészeti megközelítés számára is tanulsággal Margócsy István (1996: 251) nem túl régen a teljes újragondolás lehetőségét vagy inkább szükségességét így vetette fel: „Ha megpróbáljuk a lehetetlent, s valamelyest is elfogulatlan szemmel olvassuk újra a XVIII. század végének jó pár fontos megnyilatkozását a magyar nyelvet illetően, szinte természetesen zavarba kell, hogy jöjjünk, oly tarkabarka, oly nehezen értelmezhetö képet kapunk $-\mathrm{s}$ ha nem hagyjuk magunkat egyszerúen elhitetni a majd kétszáz éve folyamatosan hagyományozódó irodalomtörténeti tézisektől [...] s az egyes kijelentéseket, álláspontokat, tényeket a maguk helyén próbáljuk meg újra megérteni, alighanem arra a megoldásra kell, hogy jussunk: újra kell gondolni az egész helyzetet, nyelvestül, irodalmastul..." Az alábbiakban az ehhez az újragondoláshoz való hozzájárulás szándékával, annak egyik lehetőségeként vetem fel a nyelvújítás diszkurzusában megjelenő metaforák szerepének, nyelvelméleti jelentésének a vizsgálatát. Módszertani szempontból ehhez egyik leginkább inspiráló, elsődlegesnek nevezhető kiindulópontom Kertész András (2005) A nyelvészet metaforái címü, a kognitív szemantika metaforaelméletét (összegzően lásd pl. Lakoff-Johnson 1980; Kövecses 2010) metaelméleti felhasználásban alkalmazó akadémiai székfoglalójának az az alapfeltevése volt, hogy a metaforák szerepének vizsgálatával magukról a nyelvészeti elméletekről is releváns megállapításokhoz juthatunk. Ezzel összefüggésben szükséges azonban mindjárt itt leszögezni, hogy Kazinczy és a magyar nyelvújítás két nagy tábora, az „ortológus” és a „neológus” irány vonatkozásában csak tágabb értelemben beszélhetünk nyelvészeti elméletekröl, ezért is alkalmazom a következőkben inkább a nyelvszemlélet, nyelvfelfogás kategóriákat.

1 A tanulmányban ismertetett kutatómunka az EFOP-3.6.1-16-00011 jelü „Fiatalodó és Megújuló Egyetem - Innovatív Tudásváros - a Miskolci Egyetem intelligens szakosodást szolgáló intézményi fejlesztése" projekt részeként - a Széchenyi 2020 keretében - az Európai Unió támogatásával, az Európai Szociális Alap társfinanszírozásával valósul meg. 
A téma pontosabb körülhatárolása, illetve a fogalmi tisztázás részeként előzetesen érdemes röviden a nyelvújítás mibenlétére is kitérni. A nyelvújítás egy meglehetősen elterjedt vélekedéssel szemben nem tekinthető pusztán szókincsbővítésnek, tudniillik annak részeként egyaránt fontos volt a sztenderd kialakítása, rögzítése, a stílusváltozatok bővítése stb. Benkő Loránd tömör megfogalmazásával élve: ez a nyelvi mozgalom „összemérhetetlenül tágabb körü, szélesebb perspektívájú volt a szókincsgyarapításnál, mégpedig nemcsak a nyelv és a nyelven kívüli tényezők kapcsolatának alapvetően fontos területein, de akár a nyelv zártabb körén belül is, az ortográfiától a stílusig menő szélességben" (Benkő 1982: 6; vö. még Tolcsvai Nagy 2007). A nyelvtant („Grammatikai Jegyzések”-et) írni készülő Kazinczy egyik levelében ezért is sorolja a következőképpen nyelvújításának az összetevőit: „,új szavaim, új syntaxisom, új frázisaim, sok helyett egészen különböző orthographiám" (KazLev. III. 158-9).

A témához felhasználható óriási mennyiségü korpuszból (vitairatok, tanulmányok, levelezés) kiindulópontként Kazinczy az Ortológus és neológus; nálunk és más nemzeteknél címü tanulmányát (a továbbiakban: Kazinczy 1819) és levelezését (KazLev.) vettem alapul. A diszkurzus további résztvevői „literátusok, írók, költők, tanárok, papok és mükedvelők [...], akik a korszakon belül először egymástól függetlenül müködnek, majd többé-kevésbé változó táborokba, esetleg iskolákba, de nem mühelyekbe vagy paradigmákba tagozódnak be" (Tolcsvai Nagy 2004: 42). Már csak azért is, mert a következökben igen gyakran hivatkozom majd Kazinczy levelezésére, szükségesnek tartom még itt megjegyezni azt is, hogy e „túlsúly” ellenére ugyanakkor osztom Czifra Mariannak (2012: 76) Tolnai Vilmos (1929: 20) véleményére vonatkozó kételyét, miszerint Kazinczy levelezése, kétségtelen jelentősége mellett is, önmagában alkalmas lenne arra, hogy a nyelvújítást „hitelesen”, azaz komplexitásában, a maga egészének jellegét tekintve megismerjük. A jelen esetben azonban nem is a teljes kép adása, hanem egyfajta megközelítési mód felvetése és az abból adódó első elemzési eredmények és tanulságok megfogalmazása volt a célom.

A módszertanra vonatkozóan végezetül azt is meg kell említenem itt, hogy a metaforizációt vizsgálva a metaforák mellett a képi konceptualizáció más megvalósulásait is figyelembe vettem, így a hasonlatot, a képi analógiát is.

\section{A nyelv és nyelv megújításának metaforái}

A metaforizációt az alábbiakban két elkülöníthető, de jellegénél fogva és különösképpen a nyelvújítás diszkurzusában, nyelvalakító tevékenységében, tehát a vizsgált szövegekben is szorosan összefüggő területen vizsgálom: egyrészt mint a nyelvre mint valamilyennek elgondolt entitásra közvetlenül vonatkozó metaforizációt, másrészt pedig mint a nyelv megújítására, a nyelvvel kapcsolatos tevékenységre vonatkozó képi konceptualizációt.

A fenti értelemben szükebben vett, azaz közvetlenül magára a nyelvre vonatkozó metaforákban megjelenő nyelvszemlélettel kapcsolatban a legalapvetőbbnek tünő kér- 
dés a nyelvről való gondolkodásban ,alighanem az egyik legrégebbi kérdés: a nyelv eszköz vagy szubsztancia volta" (Tolcsvai Nagy 2017: 38). Röviden a két felfogás különbsége így összegezhető: az első ,,a nyelvet az egyén számára készen adott közlő eszköznek tekinti, olyan dologszerüen metaforizált entitásnak, amely a változás, a változtatás és a további tanulás szüksége nélkül a beszélö rendelkezésére áll", míg a nyelvet szubsztanciaként, lényegként értelmező nézet szerint ,,a nyelv az emberi tevékenység, méghozzá az alkotó, dinamikus cselekvések sorának a része. A nyelv és a nyelvet beszélö ember kölcsönhatásban állnak, egymást alakítják, egymást hozzák létre" (uo.).

Ez a kettősség, pontosabban az ezzel összefüggő állásfoglalás, mindenekelőtt a változás, a változtatás legitimitásának, módjának a diszkurzus középponti vitakérdéssé válásával, a nyelvújításban is meghatározó jelentőséggel merül fel. A nyelv szubsztanciaként való felfogásában, annak részeként a változás és ezzel együtt a változtatás - bár természetszerüen korlátozott - lehetőségeit kifejező, magában foglaló fogalmi metaforák kiemelkedő szerepet kapnak Kazinczy és általában a nyelvújítást támogatók szövegeiben.

Kazinczy és a nyelvújítási diszkurzus egyik leggyakoribb idetartozó fogalmi metaforája A NYELV ORGANIZMUS. Mielőtt részletesebben megvizsgálnánk néhány, ezt az alapmetaforát variáló fogalmi metaforát és metaforikus kifejezést, érdemes kitérni arra is, hogy a nyelv organizmusként való konceptualizálása nem jelenti automatikusan a neológus szemlélet vagy program elfogadását, sőt olykor éppen hogy az ortológia is kiindulópontként él ezzel a metaforával. A különbség abban áll, hogy az ortológia a nyelvet olyan önmüködő természeti organizmusként fogja fel, amelyen nem kell, nem szabad változtatni, azaz ,a nyelv ugyan változik, de azt nem az ember változtatja, ezt nem is teheti" (Tolcsvai Nagy 2004: 48). Ez az ortológus szemlélet jelentkezik Zsombori József (1815: 154-5) allegorikus megfogalmazásában:

\begin{abstract}
„Külömben is Nyelvünk még csak tavaszi korban vagyon, s nem sokára a’ fog történni vele, a' mi egy virágos fával. Majd a' felesleg való virágok lehullanak, és míg a' termés ideje elközelít, a' hasztalan fattyujövések kiasznak. Ha a' gyümölcsözés idejét maga utján siettetjük, igen jó; de soha a' dolgot ne eröltessük, mert igy többet fogunk ártani, mint használni. Minden dolognak meg-van a maga ideje. Minden növevény maga nemiben, idejében, földjében, egében, természetéhez illő tápláló szerekkel: tulajdon erejének vezetése, nevelése, nem pedig tekerése, facsarása által gyarapodik és teljesedik. Igy a Nyelv is!"
\end{abstract}

Debrecen „ortológiáját” indulatosan kárhoztató, 1805-ben Cserey Farkasnak írt levelében Kazinczy viszont A NYELV ORGANIZMUS metafora egyik jellegzetes megvalósulását, A NYELV ERDÖ analógiáját éppen ellenkező értelemben, a változás és - ahhoz nyilván hozzáértve - a változtatás természetes, szükségszerü volta melletti érvként használja fel:

„Debreczen ott akar maradni mindég, a' hol volt. Azon felyül, hogy ez az emberi lélek természetével ellenkezik, ellenkezik a' Horátz tanításaival is. Quod si tam graecis novitas invisa fuisset, etc. etc. 's a' Nyelvet öszve hasonlítja az erdőkkel, mellyek 
hullatják a' leveleiket, 's új leveleket vernek. Nézzük-el a' száz esztendővel ezelőtt élt Német írókat, és azokat a' kik 50 eszt. olta éltének, nézzük-el, melly erőszakot vittek véghez nyelveken és ez által menynyire mentek?” (KazLev. III. 303; hasonló értelemben idézi Horatiust: KazLev. III. 309).

A NYELV ORGANIZMUS fogalmi metafora különböző jelentésekkel és számos változatban jelenik meg Kazinczy és általában a neológia érveléseiben is, így gyakori A NYELV NÖVÉNYZET, azaz egyes növények együttese, nagyobb egysége, például A NYELV (VIRÁG)MEZÖ, A NYELV KERT metafora, mint ahogyan A NYELV EMBER metafora is. Az Ortológus és neológus...-ban például az idegen nyelvekből való átvétel melletti érvelésbe épül be A NYELV (VIRÁG)MEZŐ metafora:

„ha virágokat Római mezőkön szabad szedni,'s nem azért szabad, mivel a’ Római nyelv eránt nem tudom melly tekintettel tartoznánk, hanem mivel azok szép virágok: nem látjuk, miért volna vétek, hogy új Iskola itt is nyílt, 's miért legyen tilalmas virágokat az új nemzetek mezejiken is szedni, ha ezek is szépek. Példát az illy kölcsönzésre nyelvünk századok olta mutathat, 's nagy bővségben..." (Kazinczy 1819: 12).

Kazinczy Szemere Pálnak írt egyik levelében, szintén az idegen nyelvekből való átvételek legitimitása mellett érvelve, Döbrenteiével szembeállítva és így magyarázvavédve saját álláspontját, olyan (részben már köznapi használatban a képi jelleget nem is szaliens módon hordozó) metaforikus kifejezésekben bontja ki a nyelvet értelmező fogalmi metaforának a stílusra, stílusértékre vonatkozó jelentését, mint a sokszínü, szag, szín:

„Döbr. Eggyszínűvé, Kaz. Sokszínüvé akarja tenni a’ Nyelvet. (Charactersprache.) Döbr. semmit nem tür a' min idegen szag van, bár a' szag és szín kedves: Kaz. kész elfogadni mindent a' mi idegen, ha szép, és ha nálunk is szép marad; mert tudja, hogy

Külföld termése volt a' rózsa is:

A' művelés belföldivé tevé,

'S Heszpéri eget szítt e' tetők' gyümölcse” (KazLev. XX. 368).

Minden bizonnyal fóként Herdernek (1767) az emberi életkorokban jelentkező, a „rossztól” (vom Schlechten) a tökéletesedés felé vezető, majd újra visszahulló körforgásként értelmezett változást mindenre (Kreislauf aller Dinge), így nem utolsósorban a nyelvre is vonatkoztató elméletének hatására ${ }^{2}$ fontos szerepet kap a nyelvújítás diszkurzusában A NYELV EMBER fogalmi metafora. Így az Ortológus és neológus...-ban is, a változás, újítás programjának igazolásához szolgáló érvként:

2 „So wie der Menfch auf verfchiedenen Stuffen des Alters erfcheinet: fo verăndert die Zeit alles. [...] vom Schlechten zum Guten, vom Guten zum Vortreflichen, vom Vortreflichen zum Schlechtern, und zum Schlechten: diefes ift der Kreislauf aller Dinge. [...] So ifts auch mit der Sprache" (Herder 1767: 27; Herdernek Kazinczyra és a magyar nyelvújítás diszkurzusára gyakorolt nagy hatásáról lásd pl. Csetri 1990: 51-2 és passim; Tolcsvai Nagy 2004: 35-6; Bíró 2010: 422-8 és passim). 
[A nyelv] „elérvén így férjfiúi korát, vagy megfordúl útján 's a' nemzet' hanyatlásával ő is hanyatlik, vagy megifjodván a' nemzet, ő is megifjúl, 's újjá-születve szép pályáját újra kezdi. [Új bek.] A' mi Nyelvünk is ez úton éré-el serdülni kezdett ifjúi korát" (Kazinczy 1819: 7).

Ugyanakkor az alapjában kétségtelenül inkább a változást involváló A NYELV EMBER fogalmi metafora - a fent bemutatott Zsombori-idézetben megjelenő A NYELV FA fogalmi metaforához hasonlóan - a statikusság, változhatatlanság ortológ nyelvszemléletének alátámasztására is alkalmas lehet. Ahogyan például Verseghy ,azt tanítá, hogy Nyelvünk már elérte férikorusága' pontját, 's így azon igazítani, változtatni, azt bővíteni, abban újat teremteni nem szabad" (Kazinczy 2009: 553). A Révai-tanítvány Horvát István, a neologizmus táborának kiemelkedő képviselője Verseghyvel vitázva szintén A NYELV EMBER fogalmi metaforára építi gondolatmenetét, és így jut ellentétes eredményre, a magyar nyelv történeti áttekintéséből azt a következtetést vonva le, hogy a 18. század végének, sőt a „maradék”-nak is joga van a nyelvi változtatáshoz:

„a XVIII. században édes ősi vagyonunk lassanként s mintegy észrevehetetlenül az aggúlt vénséghez s ezt követö kihaláshoz közelgett. [...] sokan azon búsúltak, hogy nyelvünk temetöbe vitetik [...] Volt a mi nyelvünknek a Révai tanítása szerént is gyermeki kora, ifjúsága és férfiállapatja, de nem akkor, amikorra álmodozza ezeket az időket Verseginek tanulatlan agya. A XVI. és XVII. századról, mint férfikorról csaknem mindenütt tisztelettel szól kedves tanítónk, valamint kárhoztatja mindenütt a mostani meghasonlott szokásban a vénség idejének csúfos maradványait. De ő azonban még a férfikort sem teszi mindenben egyedűl való bírónak: mert mi nagyobb világosságra jutván többet fedezhetünk fel nyelvünk természetében. S amit Révai hallatlan szorgalmával ki nem tanúlhatott még a nyelv titkaiban, amint sokszor egyenes szívvel önkényen maga vallja: ki tanúlják azt vagy más mostani jeles írók vagy a következő maradék, mely be letekintvén mélyebb visgálással a nyelv történetébe, azt ugyan óvni fogja a XVIII. század. század végének dögös maradványaitól” (Pennaháborúk, 378-9; a kiemelések tőlem: P. J.).

A NYELV EMBER metafora egyik érdekes és gyakori variációjában a nyelv szüZként jelenik meg, Margócsy István (2006: 103) szerint ,,a nyelvújítás problémájának kapcsán e korban e metafora teljesen általánosként müködött”. Ez a konceptualizáció a korabeli (részben ma is élö) társadalmi etikának a szüzességre vonatkozó értékítéletét szemantikai tartalomként magában foglalva elsődlegesen azoknak a nyelvszemléletében jelenik meg, akik ,,a nyelvnek tisztaságát, ártatlanságát védik, s az idegen kulturális vagy nyelvi behatásnak minden fajtáját [ideértve elsődlegesen a nyelvújító tevékenységet: P. J.] organikus és erkölcsi megrontásnak élik meg" (uo.). Ezt a metaforizációt használja a Tudományos Gyüjteményben 1818-ban megjelent, A magyar nyelv fö törvényeiröl címü tanulmány szerzője, aki értekezésében „az orthographianak sarkalatos törvényjei”-t kívánja bemutatni. Úgy véli, hogy azok, akik a „régi iróknak példájokat” tekintik törvénynek „abban a buzgó hiszelemben vannak, hogy csak így nyerhet a' nyelv állandó eggyenlőséget; hogy csak így fog a' nyelv' szüzesége sérelem nélkül maradhatni; hogy különben a nyelv lassanként 
elveszti eredeti természetét, még végre a magyar nyelv nem magyar nyelv leend..." (A magyar nyelv fö törvényjeiről, 1818: 43; a kiemelés tőlem: P. J.)

Nem véletlen tehát, hogy a neológia nézőpontjából, a nyelv, pontosabban a szókincs állandó bővülésére utalva Dessewffy József ironikus gúnnyal „szedi ízekre” A NYELV SZÜZ metaforát:

„A' néha mélyebben gondolkozó Tsászár Úr, minekutána elfelejtette volna, hogy nyelvünket anyanyelvnek mondotta, aszt szüznek hirdeti, a ki minden elegyedéstől irtózik. De a' szüzek nem szaporodnak, és nem tudom, hogy lehessen a boldogságos Szüzen kívül a' termékenységet a' Szüzességgel össze egygyeztettni. Nem merem reménleni, hogy a Szent Lélek Úr Isten sugja nékünk mindenkor az új Magyar szavakat" (KazLev. IV. 403).

A NYELV EMBER metafora forrástartományának egy újabb aspektusa bomlik ki Kazinczy levelének következő részletében, ahol az olyan metaforikus kifejezések mint a szabad, a maga gustussa, a szolgájává tulajdonképpen a nyelv univerzális és specifikus (nyelvspecifikus) voltának kérdésére mutatnak: „a’ mi nyelvünk szabad élő nyelv lévén, nem köteles, hogy mindenben rabszolgája legyen a’ régieknek követésében, hogy azokkal maga gustussa szerint ne élhessen. Illő, hogy ha más nemzetet követünk valamiben, ne tegyük épen magunkat az ő szokásoknak szolgájává, hanem éljünk magunk élő szabadságunkal” (KazLev. XIV. 475).

A fentiekben A NYELV ORGANIZMUS metaforát, illetve annak variánsait vettük szemügyre, és mint láttuk, ezek a nyelvújítási diszkurzusban föként a változás, változtatás melletti vagy elleni érvelésben jelentkeztek. Most csak rövidebben, kevesebb példával térek ki arra, hogy természetesen más nyelvmetaforákat, illetve metaforarendszereket is lehetne vizsgálni ennek az argumentációnak a részeként, ilyen például az Ortológus és neológus...-ban is szereplö A NYELV FOLYó metafora. A folyó az ókortól kezdődően az állandó változás toposza, tehát nem meglepő, hogy ez a metafora (vagy a folyó képi analógiája) a neológusok írásaiban a nyelv dinamikus voltának gyakori képi megjelenítése, mint ahogyan a következő esetben is: „Egyedül a' kiholt nép' nyelve nem változik többé: az élő népek' nyelve minden nyomon változik, 's örökké fog változni, hasonló a' Horátz' folyamjához, mellynek elfutását a' paraszt csak várja, 's az még is fut, változik, 's az marad a' mi volt' (Kazinczy 1819: 7).

A nyelvi változtatás, a neológia legitimitását érintő, egyúttal a neológia és az ortológia közötti különbség szempontjából is az egyik legalapvetőbb kérdés a nyelvújítás diszkurzusában a „kié a nyelv?” (vö. Bíró 2010: 554-5) kérdése. A sors iróniájának fogható fel ebben a vonatkozásban, hogy napjainkban számos helyen Kazinczyhoz mint szerzőhöz kötve bukkan fel az általa ingerülten, azaz emocionálisan, ám erős elvi alapon elutasított, valójában Zsombori Józseftől (1815: 155) származó, aforisztikusan jól hangzó kijelentés: „Jó igen jó vólna, minden Magyar Irónak, elöre meggondolni azt, hogy a' Nyelv nem az enyim sem nem a'tied, hanem édes miénk". Nem véletlen, hogy maga Kazinczy a nagybetüs írásmóddal hangsúlyozza a Zsomboriétől gyökeresen különböző véleményét az Ortológus és neológus...-ban: „A' Nyelv MIÉNK, és így ENYÉM is” (Kazinczy 1819: 19). E gondolat részletezésé- 
ben is fontos és többértelmü szerepet kap A NYELV FOLYó (FOLYAM) metafora: „Az egész társaság' folyamjával az egész társaság parancsol: annak telkemen keresztül futó erével tehetem a' mit én ítélek czélomra hasznosnak. És ha azt azért zavarom-fel, hogy medrét mélyebbé tegyem, vagy egyenesbb futásba vegyem, igyekezetemet minden Jó javallani fogja" (Kazinczy 1819: 19-20). Az allegóriává kibontott folyómetafora a nyelvszemlélet szempontjából több fontos eleme miatt is figyelemre méltó, így például az egyén és a közösség szerepe, jogai és lehetőségei a nyelv alakításában vagy a célszerüség („haszon”) mint a változtatás motivációja szempontjából. Nem érdektelen a „felzavarás” jelentésmozzanata sem, amelynek egyik lehetséges értelmezése a nyelvújítási „harcokra” való vonatkoztatás.

A szabadság és a kötöttség alapvető kettőssége nemcsak az egyén és a közösség nyelvhez való viszonyának kérdéskörében, hanem A NYELV ORSZÁG, A NYELVI RENDSZER TÁRSADALMI RENDSZER fogalmi metaforákban is a fókuszban áll. Az idetartozó metaforizációban a nyelvi rendszer vagy a nyelvhasználat érthető módon föként a korabeli monarchikus társadalom- és államszervezet analógiájával konceptualizálódik: „azt tartom, hogy a' nyelv szokásának tyrannismusát sok helyett tisztelnünk kell” (Kazinczy Kis Jánosnak; KazLev. VIII. 32), „Az usus nagy tyrannus; ’s sok esetben parancsol a' Grammatikának” (Kazinczy Buczy Emilnek; KazLev. XII. 432). Csokonai alábbi okfejtésében más összefüggésben, funkcióval áll A NYELV ORSZÁG fogalmi metafora, az idegen szavak átvétele, ,honosítása” kap alátámasztást kifejtésével:

„Én a’ szókat úgy nézem a’ nyelvben, mint a’ polgárokat a’ hazában. [...] Vagynak [...] ollyanok, a' mellyek eredet szerént ugyan nem magyarok; de vagy a' Nyelv' Királyától, az Usustól, petsétes levelet kaptak, vagy a' Magyar Tudósok’ Diétáján hungarizáltattak, Ezek Indigenák és Libertinusok: és ezekben, ha polgári just kívánnak szerezni, megkívánhatja a' Nemzet, hogy a' tős-gyökeres Magyar szók felett, se nyilván se titkon, sem erővel sem szép szín alatt, elsőségre ne héjjazzanak, hogy külföldi ruhájokat levetkezzék, idegen hangejtéseket megszelídítsék, és még a' legutolsó Magyar jobbágy' füleinek is botránkozást ne tsináljanak, 's annak száját elviselhetetlen rabotával ne nyomorgassák. Igy áll fel osztán törvényesen a' Magyar Nyelv' országa; így szaporodnak miriádokra annak hasznos és díszes polgárjai” (Csokonai 1802).

Az e részben tárgyaltak tágabb, kor- és történeti összefüggésben való elhelyezéseként, ${ }^{3}$ az eszme- és stílustörténeti háttér felvázolásaként legalább röviden arra is érdemes kitérni, hogy a nyelvújítás diszkurzusában megjelenő, fent bemutatott metaforák - különösen A NYELV ORGANIZMUS fogalmi metafora és ennek alterációi - nem csupán egyetemesek, hanem szorosan a korhoz is kötődnek, azaz széles körben ismert fogalmi összefüggésekként müködtek és hatottak a klasszicizmus, szentimentalizmus és a romantika határán, az európai müvelődésben. Míg a racionalista felvilágosodás számára a nyelv jellemzően puszta eszköz, „egy már meglevő, az embernek rendelkezésére álló, de mindenkori hangulatától, érzéseitől független va-

3 Itt köszönöm meg Tolcsvai Nagy Gábornak, hogy felhívta figyelmemet ennek az elhelyezésnek a szükségességére; ez valóban olyan fontos vonatkozás, amely akár egy külön dolgozatot is megérdemelne. 
lóság [...], létező »res«, de élet nélkül [...], séma, gép, az emberi lélektől idegen, eszközszerü valóság” (Szekrényessy 1937: 11), addig a herderiánus és általában az ekkor kibontakozó romantikus felfogás számára már éppen hogy emberi jellegü, az emberhez hasonló organizmus. Bopp sokszor idézett 1827-es összegzése szerint: „A nyelveket olyan természetes lényeknek kell tekintenünk, amelyek meghatározott törvények szerint jönnek létre, magukban egy belső életelvet hordozva fejlődnek ki, és aztán fokozatosan elhalnak” („Die Sprachen sind als organische Naturkörper anzusehen, die nach bestimmten Gesetzen sich bilden, ein inneres Lebensprinzip in sich tragend sich entwickeln, und nach und nach absterben; Bopp, Franz 1827/1836: 1). Az ebben a metaforában esszenciálisan megjelenő szemléletmód aztán a 19. század olyan nagy hatású nyelvészeti munkáiban és irányzataiban jelenik meg alapként, illetve kap részletező kifejtést, mint Becker (1827) Organism der Sprache címü könyve vagy a családfaelmélet kidolgozójának, August Schleichernek és követőinek a munkássága.

\section{A ,szép játék": a különbözés egysége}

A nyelvújítás egyik legfontosabb területe az elsősorban nyelvesztétikai megfontolások alapján megközelített differenciáció volt (részletesen bemutatja ezt például Tolcsvai Nagy 2004: 32-6; 2007; 2009), amely az Ortológus és neológus...-ban is középpontban áll. Kazinczy itteni, gyakran idézett szembeállítása szerint „az Orthologusokat ez az Eggység' üzése vitte tévelygésre, mert a' mit a' Stilisticának csak némelly nemeire kellett volna kiterjeszteniek, általjában minden nemeire terjesztik-ki. [...] Eggy szóval, ők az EGGYSÉG‘ EGGYSÉGÉRE törekszenek, melly csak a“ speculáló Bölcs' káprázolatiban találtatik: a’ Természet mind a’ testi mind a' lelki világban mindent a’ KÜLÖMBÖZÉS ‘ EGGYSÉGE (Concordia Discors) által tenyésztet, mindent az által tart-fenn, 's a’ Neologus ezt követi” (Kazinczy 1819: 18-9). A Concordia Discors elve Kazinczy életmüvében ebböl következően is természetesen gyakran megfogalmazódik (lásd pl. KazLev. XI. 173; KazLev. XVI. 49 stb.), nemegyszer metaforikus konceptualizációban, hasonlatban, mint az Ortológus és neológus... alábbi, A NYELV SZIVÁRvÁNY fogalmi metaforára épülő részében:

„A' nyelv ollyan mint az ég’ íve a’ maga egymásba-futó színeinek gyönyörü játékával. Elbontja a' szép játékot, a' ki a' színeket a' magok nemeikre akarja osztani. Hadd játszák játékokat itt is a' törvény, szokás, analogia, euphonia, ízlés, régiség, újság, magyarság, idegenség, hideg józanság 's poetai szállongás, 's hagyjuk a czirkalmat és lineát máshova" (Kazinczy 1819: 24).

Filológiai szempontból is érdekes lehet, hogy ennek a hasonlatnak a közvetlen előzményét olvashatjuk Kazinczy Szentmiklóssy Alajosnak 1818. február 27-én írt levelében: „Nekem úgy tetszik, hogy a' Nyelv nagyon jól hasonlít az ég' ívéhez: ebben is a' színek ugy folynak egymásba, hogy a' szem meg nem kaphatja a' külömbözés határ vonásait, de hogy más a’ kék szín, más a’ veres, más a’ fejér, azt jól látja” (KazLev. XXIII. 260). A különbözés egységének sokszínüsége, ,szabályozott 
szabadság"-a, azaz a helyzethez és a nyelvhasználóhoz alkalmazott nyelvhasználat eszménye és követelménye más metaforákban is kifejezést kap. Például A NYELVHASZNÁLAT TÁNC metaforában is, amely a kötöttség és kötetlenség egységét, azaz a kötött séma tudásával, de mégis másként, akár még „hamisan” is megvalósuló alkalmazás lehetőségét az Ortológus és neológus...-ban így fogalmiasítja: „Hamisan lépni a' tánczban csak annak szabad, a' ki tánczolni igen jól tud” (Kazinczy 1819: 25).

A Kazinczyéval rokon, a nyelv „,örvényes regulátlanságát” szintén megengedő felfogást mutat Teleki Józsefnek A NYELV KERT fogalmi metaforát az angolkert és a franciakert összehasonlításával kibontó gondolatmenetének a konklúziója: „,Meg kell tehát tartanunk nyelvünknek mostani regulásságát, azt a' legnagyobb féltékenységgel örizvén, tsak azon részeit ne bántsuk a' hova a' kertésznek kérlelhetetlen ollója nem jutott, tsak ott hagyunk a' fáknak szabad növést hol ez a' nagy egész regulásságának nem árthat” (Teleki 1816/1821: 316). Talán nem érdektelen itt megjegyezni, hogy az angol- versus franciakert témája Kazinczy írásaiban, leveleiben is többször előkerül (ehhez lásd pl. Granasztói 2010; Bódi 2014), olykor a konkrét, referenciális jelentésen túlmutatva, általánosító érvénnyel, a metaforikus értelmezés lehetőségét is megnyitva, mint például a hotkóci angolkertről írt beszámoló következő részletében: „de viszsza tértünk e' a' természethez? azt tettük e' a' mit minden szépitő mesterségnek tenni kell, hogy a természetnek segédjére keljen?" (Kazinczy 1806: 278; a kiemelés Kazinczytól).

\section{Háború és per: a nyelvújítás vitái}

Minden bizonnyal a nyelvújítás legismertebb metaforái A VITA HÁBORÚ fogalmi metafora különböző variációi. Ezek nem csupán a nyelvújítás korának diszkurzusában töltöttek be meghatározó szerepet, hanem mind a mai napig elevenen tovább élnek az e diszkurzust értelmező recepcióban is. Ahogyan Czifra Mariann (2011: 326) írja: „ez a metaforika olyannyira hozzátapadt Kazinczyhoz, s általa a tízes évek vitairodalmához, hogy szinte részévé vált a róla, s egyben a korszakról való beszédnek". Példaként hadd utaljak most csak az újabb szakirodalomból Bíró Ferenc (2010) a nyelvújítást tárgyaló nagy összefoglalásának címére: A legnagyobb pennaháború és e munka olyan fejezetcímeire, mint Az új ellenfél: „Debrecen”; Széphalom ostroma, Békekötés.

Kazinczy részéröl a CSATA/HÁBORÚ metafora használata nagyon is indokolt volt, hiszen szándékosan akarta élezni az ellentéteket, így provokálva a vélemények kifejtésére a grammatikusokat, az írókat, azaz mindkét oldal: az ortológia és a neológia híveit egyaránt, mivel meggyőződése volt, hogy „a’’ tudománybeli csatáknak meg van a' magok haszna; a' dolog jobban kiőrlődik, opinionum commenta delet dies, rationis iudicia confirmat, 's azok az ideák, mellyek annakelötte csak kevés föben voltanak-meg, 's talán ott is csak homályosan, elhatnak a' Publicumra, 's közönségessé lesznek" (KazLev. IV. 373; vö. még KazLev. XIII. 487-8). Optimizmusa nemcsak a végkifejletre vonatkozott, hanem magának az elvek ütköztetésének módjára is: „Egyedül azt óhajtom, hogy ha a' csatázók élesen szóllanak ’s tűzzel 
bánnak is egymással, ne fakadjanak alacsonyságokra” (KazLev. IV. 375). Az „alacsonyságokra fakadásnak", a személyeskedő, durva támadásoknak azonban nagyon is fennállt a veszélye, és nemegyszer valóban idáig fajult a vita. Van, aki a „háborús metaforikának" ebben meghatározó szerepet tulajdonít (lásd Onder 2010; vö. Lakoff-Johnson 1980: 4-7), ez azonban minden bizonnyal még további vizsgálatokat igényel.

A vITA HÁBORÚ mellett az elvek ütköztetésének másik, az Ortológus és neológus... -ban is lényeges szerepet kapó fogalmi metaforája (vö. Onder 2009) a HÁBORÚ metafora szerkezetéhez és szemantikai összetevőihez sok tekintetben hasonló A VITA PER: „A' melly nemzeteknél a’ Helicon’ járvány Istenségei korábban foghatának lakást, mint eggynél több 's nagy okok miatt nálunk, a' Nyelv eránt támadott peren, nagyjában tekintvén a' viszálkodást, régen által estek: mi, kiknél a' dolog nem segélteték úgy mint máshol, 's a' kik így Philologiai isméretekben halkabban haladhatánk; most perlünk egymással" (Kazinczy 1819: 3-4; az Ortológus és neológus Tudományos Gyüjteményben megjelent változatától bővebb, második kidolgozásában még nagyobb szerepet kap ez a metafora, lásd Czifra 2013: 267).

A „klasszikus” VITA HÁBORÚ metaforához kötődő metaforikus kifejezés (megfújták a' kürtöt) és allúzió (Hannibál a' kapuk elött) mellett a hitviták, a felekezeti ellentétek metaforikája (schismát csinálok a’ nyelvben; az ö Grammatikai egyedül idvezitő hiteken stb.) jelenik meg a következő levélrészletben, amelyet, akár csak arra gondolva, hogy a nyelvújításnak mennyire markáns felekezeti vonatkozásai voltak (vö. pl. Csetri 1990: 32), valószínüleg nemigen tekinthetünk puszta esetlegességnek: „Most megfújták a’ kürtöt, hogy Hannibál a’ kapuk előtt áll, hogy én schismát csinálok a' nyelvben; én pedig azt a' panaszt teszem ellenek, mint igen buzgó Protestáns, hogy ök el akarják fojtani a’ lelkiismeret szabadságát és valaki az ő Grammatikai egyedül idvezítő hiteken kívül van, mind arra anathémát kiáltanak" (KazLev. XV. 124).

\section{5. Összegzés}

A nyelvújítás diszkurzusában megjelenő fogalmi metaforák, különösen e metaforák nemegyszer részletező, olykor allegorikus jellegü kidolgozásai a diszkurzusban részt vevők nyelvszemléletének számos lényeges vonását előtérbe helyezik. Mivel a fentiekben elsősorban Kazinczy szövegeit vizsgáltam, az összefoglalásban is az ő nyelvfelfogására, nyelvújítási programjára vonatkozó legfőbb elemeket lehet a leginkább megalapozottan kiemelni. A metaforikus konceptualizációban a leginkább szembetűnőek azok az elemek, amelyek azt igazolják, hogy Kazinczy nyelvértelmezése, nyelvszemlélete - mint ahogyan az ittenitől eltérő kiindulópontból és jóval tágabb összefüggésrendszerben Tolcsvai Nagy (2009) is bemutatja - mai nézőpontból is funkcionális megalapozottságúnak minősül. Az a már előzményeiben Herdernél is jelentkező, de majd Humboldt (1985: 102) nyelvelméletében kifejtett meglátás, hogy a nyelvet „nem tekinthetjük kész, egészében áttekinthető vagy lépésről lépésre közölhető anyagnak", a neológiában is fontos szerepet kap. A funkcionális nyelvfel- 
fogás következő előfeltevései, mint azt a metaforaelemzések igazolják, meghatározóak Kazinczy és a neológia szemléletében: a nyelv történeti jelenség, amely időben változik; a nyelvi rendszer dinamikus használati lehetőségei egyszerre engedik meg a rendszer stabilitását és szükség szerinti alakítását, egy nyelv közösségi és egyéni változatokban müködik, azaz a nyelv egyszerre egyéni, személyes és közösségi (vö. Tolcsvai Nagy 2015).

Kazinczynak és általában a neológiának a magyar nyelv és a nyelvről való gondolkodás későbbi alakulásában, mint köztudott, számos releváns vonatkozásban is döntő jelentőségű hatása volt, ez a belátás a nyelvújítással foglalkozó szakirodalom jelentős részében megjelenik. Az azonban, hogy e hatásban része volt a metaforákban kifejtett elveknek, fogalmaknak, pontosabban fogalmazva: az, hogy ez a kifejtés éppen metaforákkal, illetve hogy milyen metaforákkal valósult meg, igen ritkán kerül szóba. Ezért is remélhető, hogy a metaforikus konceptualizáció szerepének további feltárása hozzájárulhat a nyelvújítás és annak hatásai teljesebb megértéséhez.

\section{SZAKIRODALOM}

Benkő Loránd 1982. Kazinczy Ferenc és kora a magyar nyelvtudomány történetében. Akadémiai Kiadó, Budapest.

Bíró Ferenc 2010. A legnagyobb pennaháború. Kazinczy Ferenc és a nyelvkérdés. Argumentum Kiadó, Budapest.

Bódi Katalin 2014. Gólyafészek és angolkert Az Árkádia-per kontextusai Kazinczy Ferenc folyóirat-közleményeiben és levelezésében. Irodalomtörténeti Közlemények, 802-831.

Czifra Mariann 2011. A „nyelvújítási harc” korlátai. Egy kognitív metafora értelemképző szerepe a nyelvújítás narratívájában. Irodalomtörténet 3: 321-40.

Czifra Mariann 2012. Szövegek hálójában. A Kazinczy-levelezés kánonképző szerepe a nyelvújítás narratívájában. Széphalom 22: 53-76.

Czifra Mariann 2013. Kazinczy Ferenc és az ortológusok. Ráció Kiadó, Budapest.

Csetri Lajos 1990. Egység vagy különbözöség: Nyelv-és irodalomszemlélet a magyar irodalmi nyelvújitás korszakában. Akadémiai Kiadó, Budapest.

Granasztói Olga 2010. Kazinczy és korai angol tájképi kertek Magyarországon. In: Debreczeni Attila - Gönczy Monika (szerk.): Ragyogni és munkálni. Kultúratudományi tanulmányok Kazinczy Ferencröl. Debreceni Egyetemi Kiadó, Debrecen, 193-206.

Humboldt, Wilhelm von 1985. Válogatott irásai. Európa Könyvkiadó, Budapest.

Kertész András 2005. A nyelvészet metaforái. In: Vizi E Szilveszter (szerk.): Székfoglalók a Magyar Tudományos Akadémián 2001. Társadalomtudományok. Magyar Tudományos Akadémia, Budapest, 59-77.

Kövecses, Zoltán 2010. Metaphor. A practical introduction. Oxford University Press, Oxford, New York.

Lakoff, George - Johnson, Mark 1980. Metaphors we live by. The University of Chicago Press, Chicago, London.

Margócsy István 2006. „Istennőm, végzetem, mindenem, magyar nyelv!” A magyar nyelv kultikus megközelítései. Beszélő I. rész: 10: 95-109; II. rész: 11: 90-8.

Margócsy István 1996. A magyar nyelv státusa a XVIII. század második felében. In: Debreczeni Attila (szerk.): Folytonosság vagy fordulat? A felvilágosodás kutatásának idöszerü kérdései. Kossuth Egyetemi Kiadó, Debrecen, 251-9. 
Onder Csaba 2010. A legjobb szándékok. A nyelvújítási harc néhány vonásáról. Árkádia (Szakmódszertani portál) http://www.arkadiafolyoirat.hu/index.php/1-a-nyelvujitaskora/109-a-legjobb-szandekok-a-nyelvujitasi-harc-nehany-vonasarol. (A letöltés ideje: 2019. 12. 30.)

Onder Csaba 2009. „...ö lesz dictátor közöttünk?” A Nekrológ-ügy Kazinczy hatalmi stratégiájában. In: Illetlen megjegyzések. Tanulmányok és esszék. Ráció Kiadó - Szépirodalmi Figyelö Alapítvány, Budapest, 151-70.

Szekrényessy Margit 1937. Romantika a német és magyar nyelvfilozófia tükrében. Minerva, Budapest.

Tolcsvai Nagy Gábor 2004. Alkotás és befogadás a magyar nyelv 18. század utáni történetében. Áron Kiadó, Budapest.

Tolcsvai Nagy Gábor 2007. 1813. A nyelvi és irodalmi ízlésvita nagy, nyilvános szakasza. Mondolat. In: Szegedy-Maszák Mihály (szerk.): A magyar irodalom történetei II. Gondolat Kiadó, Budapest, 40-56.

Tolcsvai Nagy Gábor 2009. A különbözés egysége. Kazinczy nyelvértelmezésének funkcionális alapjai. Magyar Nyelv 105: 263-70.

Tolcsvai Nagy Gábor 2015. A nyelvtudomány szerepe a tudás és a közösségi lét megalapozásában. Magyar Tudomány 2: 172-7.

Tolcsvai Nagy Gábor 2017. A nyelv kulturális, ideológiai értelmezése. In: Tolcsvai Nagy Gábor (szerk.): A magyar nyelv jelene és jövője. Gondolat Kiadó, Budapest, 32-45.

Tolnai Vilmos 1929. A nyelvújitás. A nyelvújitás elmélete és története. Magyar Tudományos Akadémia, Budapest.

\section{FORRÁSOK}

A magyar nyelv fö törvényjeiről 1818.= G. L.: Tudományos Gyüjtemény 1818. VIII., 39-66.

Becker, Karl Ferdinand 1827. Organism der Sprache. Verlagsbuchhandlung von Ludwig Reinberg, Frankfurt am Main.

Bopp, Franz 1827/1836. Über J. Grimm's deutsche Grammatik. In: Bopp, Franz: Vocalismus oder sprachvergleichende Kritiken über J. Grimm's deutsche Grammatik und Graff's althochdeutschen Sprachschatz mit Begründung einer neuen Theorie des Ablauts. Nicolaische Buchhandlung, Berlin.

Csokonai 1802. = Csokonai Vitéz Mihály: Előbeszéd [A’ Tavaszhoz]. MTA-DE Klasszikus Magyar Irodalmi Textológiai Kutatócsoport: Csokonai Vitéz Mihály összes müvei. Elektronikus kritikai kiadás. http://deba.unideb.hu/deba/csokonai_muvei/text.php?id=csokonai_ tan_04_k. (A letöltés ideje: 2019. 12. 28.)

Herder 1767. = Herder, Johann Gottfried von: Ueber die neuere Deutsche Litteratur. Bd. 1. Riga. 1767.

Kazinczy 1806. = Kazinczy Ferenc: Hotkócz - Anglus kertek. Hazai Tudósitások 1806/33: 276-279.

Kazinczy 1819. = Kazinczy Ferenc: Orthologus és Neologus; nálunk és más Nemzeteknél. Tudományos Gyüjtemény 1819/XI: 3-27.

Kazinczy 2009. = Kazinczy Ferenc: Pályám emlékezete. Sajtó alá rendezte: Orbán László. Debreceni Egyetemi Kiadó, Debrecen, 2009.

KazLev. = Kazinczy Ferenc levelezése. I-XXI. Közzéteszi dr. Váczy János. Magyar Tudományos Akadémia, Budapest. 1890-1911/XXII. (I. pótkötet). Közzéteszi: Harsányi István. Magyar Tudományos Akadémia, Budapest. 1927/XXIII. (II. pótkötet). Közzéteszi: Berlász Jenő, Busa Margit, Cs. Gárdonyi Klára, Fülöp Géza. Akadémiai Kiadó, Budapest, 1960. 
Pennaháborúk = Pennaháborúk. Nyelvi és irodalmi viták. 1781-1826. Összeállította: Szalai Anna. Szépirodalmi Könyvkiadó, Budapest, 1980.

Teleki 1816/1821. = Teleki József: A' Magyar Nyelvnek Tökélletesítése új szavak és új szóllásmódok által. In: Horvát István: Jutalom feleletek a’ magyar nyelvröl, a' Magyar Nemzeti Museum 1815. 1816. 1817. esztendei kérdéseire. Trattner János Tamás, Pest.

Zsombori 1815. = Zsombori József: Egy-két észrevétel a’ magyar nyelv mostani állapotjáról. Erdélyi Muzéum. Harmadik Füzet. Trattner János Tamás, Pest, 1815, 152-170.

\author{
Pethö József \\ fóiskolai tanár \\ Miskolci Egyetem BTK \\ https://orcid.org/0000-0002-5680-6738
}

\begin{abstract}
SUMMARY
Pethö, József

\section{Metaphorisation and attitudes to language in the discourse of the Hungarian language reform movement}

The paper discusses the role and linguistic-theoretical meaning of metaphors appearing in the 18th-century Hungarian language reform movement. The corpus is mainly provided by Ferenc Kazinczy's contemporary study "Orthologist and neologist [i.e., conservatives and moderns from the aspect of language use] in Hungary and abroad" and his correspondence, besides other documents of the period (studies and pamphlets). Of the metaphors pertaining to language and language reform, the study interprets the conceptual metaphors "LANGUAGE IS AN ORGANISM" and "LANGUAGE IS A RIVER" and their variations in detail. As far as the debates surrounding the language reform are concerned, the study discusses the metaphors "DEBATE IS WAR" and "DEBATE IS A LAWSUIT." As the interpretation of these metaphors reveal, the following presumptions of the functional concept of language are crucial in Kazinczy's and the neologists' view: language is a historical phenomenon, changing in the course of time; the dynamic possibilities of language use simultaneously allow for the stability of the system and its transformation if necessary; language operates in communal and individual variations, that is, language is communal and individual or personal at the same time.

Keywords: Hungarian language reform movement, language theory, conceptual metaphor, language as a living organism vs. language as an artifact, functional linguistics 